\title{
Individual Satisfaction and Tax Morale: The Perspective of Different Profession in Indonesia
}

\author{
Elisa Tjondro \\ Dept. of Accounting, Petra Christian University, \\ T Building $3^{\text {rd }}$ floor, Jl.Siwalankerto 121 - 131, Surabaya, Indonesia \\ Email: elisatjondro@petra.ac.id
}

Received: April 9, 2018 Accepted: May 4, 2018 Online published: May 21, 2018

doi:10.5296/jpag.v8i2.13168ＵRL: https://doi.org/10.5296/jpag.v8i2.13168

\begin{abstract}
The purpose of this research is to test the dominant factors that affect satisfaction and tax morale from the perspective of tax consultants and contractors in Indonesia. The factors are the religious commitment, trust to the government agency, the democratic system, perception of other taxpayers. The sample of respondents is 60 tax consultants and 78 contractors in Surabaya-Indonesia. Structural Equation Modelling used in this research with Wrap Partial Least Square as a statistical tool. Our result for tax consultants shows satisfaction and democratic system are the dominant factors that affect tax morale. The results from contractors found religious commitment and the democratic system was proven to be the dominant factors that affect tax morale. This study also found that trust in the government agency has not proved to have an impact on tax morale, for both groups. Factor perception of others taxpayers was proven impact on tax morale, but the effect is small, for both groups respondents. Religious commitment also proved as the dominant factor that affects satisfaction of tax consultants.
\end{abstract}

Keywords: individual satisfaction, tax morale, religious commitment, democratic system, trust to the government agency, perception of others taxpayers

\section{Introduction}

This research does deepening related individual satisfaction and taxpayers awareness to obey paying the tax. The first objective of this research proves that individual satisfaction has a significant influence on tax morale in Indonesia. Individual satisfaction was proxied with financial condition and level of happiness used in Torgler (2004a). The second objective is to know the dominant factors that affect individual satisfaction and tax morale from the perspective of tax consultants and contractors. This research suspect profession of taxpayers 
affects the determination of dominant factors in influencing individual satisfaction and tax morale. Factors that expected to affect satisfaction and tax morale are the religious commitment, trust in the government agency, democratic system, and perception of others individuals. Professional tax consultant was chosen because they often face an ethical dilemma in doing their professionalism, integrity, pressure from the client and the government, and on the other hand they face competitive environment as a professional tax consultant. They fully understand the regulation, law, and fiscal policies, but on the other hand, they were tied to professional's code of conduct. The professional organization of Indonesia Tax Consultant called IKPI has a rule (Indonesia Tax Consultant Organization, 2014) like in second part of our $4 \mathrm{a}, 4 \mathrm{~b}, 5 \mathrm{a}$, and $5 \mathrm{~b}$ is

"Upholding integrity, dignity, and honor: by maintaining public trust, being honest and lay on the line without sacrificing the recipients of services; Be professional: always use moral judgment in delivering the services, always act within service framework and respect public and government trust."

Finn et al. (1988) who performed a survey of public accountants in the USA find that tax issue dilemma is the toughest matter of ethics among others, like client's pressure to change information in the tax return. Leung and Cooper (1995) found three highest ethical dilemmas that were most frequently facing by accountants are client's proposals for tax evasion. Due to the strengthened ethical dilemma, tax consultants have a higher assertion toward government agency, democratic systems, and individual satisfaction, which ultimately affects the determination of dominant factors affect satisfaction and tax morale. In Indonesia before December 2014, the license of tax consultant was issued by the professional organization of Indonesia Tax Consultant Organization (IKPI). But the rule was changed since the issuance Regulation of the Minister of Finance No 111 / PMK.03 / 2014 about Tax Consultant. The license is the authority of the Director General of Taxes. This regulation is issued to discipline the tax consultant profession, in which one of the rules is obliged tax consultants to submit their financial statements to the Director General of Taxes on a regular basis. Since the enactment of tax enforcement in 2014 in Indonesia, the profession of tax consultants became the most sought-after profession of a private and corporate taxpayer, so that this profession experienced a significant increase in income, especially in a big city, for instance, Surabaya.

Contrast with tax consultants; contractors generally do not fully understand the rules, laws, and policies of taxes. They are also not bound by the tax code of ethics, nor do they face the ethical tax dilemma in their work. Their focus only on enlarging profit and cash flow so that their business can sustain. For contractors, taxes are part of operating expenses but have to be paid for the company to sustain. The contractors were chosen because since the end of 2012 the value of property in big cities of Indonesia, including Surabaya has increased significantly. Infrastructure development in Surabaya helped to increase property prices in Surabaya and surrounding areas. As a result, their income increased significantly, resulting in higher tax payments. The income tax for contractors in Indonesia uses gross income as the tax base. This causes the increase in gross income of the business directly affects the amount of tax payable. This reason makes contractors is the most appropriate respondent in this study to be compared with tax consultants. 


\section{Al Macrothink}

Journal of Public Administration and Governance

ISSN 2161-7104

2018, Vol. 8, No. 2

The city of Surabaya was chosen in this study because in 2014 Surabaya was the city with the highest tax revenue in Indonesia, around Rp 8.9 trillion per year, an increase of $27 \%$ over the previous year (Wibowo, 2014). A large number of investment entering the city of Surabaya caused a significant tax increase. Besides, the profession of tax consultants and construction service entrepreneurs in Surabaya is experiencing a significant increase in income.

The first research contribution is that this study is the first attempt to compare tax morale from the perspective of two different professions, that is tax consultants and contractors. Reviewing the mindset of these two different professions can provide a deeper understanding of tax morale from two different points of view. The second contribution is to provide an understanding of the influence of individual satisfaction, trust in government, democratic system, and religious commitment to increase tax morale in Indonesia, both from the perspective of tax consultants and contractors. The improvement of the quality of life which are the Indonesian government program since 2014 and transparency through e-government, expected can increase tax morale of taxpayers in Indonesia, especially tax consultants and contractors. The third contribution is to provide an understanding of the dominant factors that affect individual satisfaction and tax morale of both professions so that the government can be more focused on increasing tax morale in Indonesia.

\section{Literature Review}

\subsection{Individual Satisfaction and Tax Morale}

The intrinsic factor that is allegedly influencing its influence in Indonesia is individual satisfaction. Indonesia's human development index from 1990 to 2015 has increased by $30.5 \%$ from 0.528 to 0.689 (United Nation Development Program, 2016). Based on data released by Wealth Health Organization (World Life Expectancy, 2015),Indonesia life expectancy for men is 67 years and women 71.2 years and ranked 113th in the world. Since 2014 the Indonesian government has focused on human development through four programs, which is: "Smart Indonesia" (Indonesia Pintar), "Healthy Indonesia" (Indonesia Sehat), "Working Indonesia" (Indonesia Kerja), "Prosperous Indonesia" (Indonesia Sejahtera) (Office Staf President, 2015). "Smart Indonesia" is the program that facilitates twelve years of unpaid education for Indonesian. "Healthy Indonesia" provides health services without levees. "Working Indonesia" is the distribution of agricultural land for farmers and unemployed workers. The last one "Prosperous Indonesia" is achieved through the provision of subsidized housing and social security. The government's continuous improvement in the quality of life program expected to play a significant role in increasing the tax morale and tax compliance in Indonesia.

Torgler (2003) and (2004a) researched in Latin America and Asia, found that financial satisfaction and happiness were affecting tax morale. Gintis et al. (2008) state that the fundamental human being is moral beings, human beings get pleasure by doing ethical acts, but humans will feel guilty when doing unethical acts. Judging from an ethical point of view, paying taxes raises happiness, so when repeatedly done leads to a feeling of happiness. (Sá, Martins, \& Gomes, 2015) conducted a study in Portugal proving individual satisfaction affecting tax compliance. 
H1: Individual satisfaction has a significant influence on tax morale

\subsection{Religious Commitment, Individual Satisfaction, and Tax Morale}

(Mohdali \& Pope, 2014) who researched religious commitment found that intrapersonal religious commitment has a stronger effect than interpersonal religious commitment. Intrapersonal religious commitment is an individual commitment derived from individual beliefs and attitudes, while interpersonal religious commitment is a commitment derived from individual activism in religious organizations or communities (Pope and Mohdali, 2010). Research Okulicz-Kozaryn (2010) proved religiosity makes people happy, especially in a religious nation, like Indonesia. This happiness comes from the religious community that formed the "need to belong" in their community. Like Mohdali and Pope (2014) that proxied religious commitment on two dimensions (intrapersonal and interpersonal), so that our research uses religion activity and individual belief, to measure religious commitment.

Religious commitment is how much level of understanding in religious belief, values, and its application in the daily life of the taxpayers (Worthington et al., 2003). The principle of religion is teaching the community to act by prevailing norms and laws and to emphasize sanctions, as a result of violations of social norms and applicable law. Research Mohdali \& Pope (2014), which conducted on taxpayers in Malaysia, found that religious commitment was positively influencing tax compliance voluntarily. The culture of Malaysian society that tends to have strong religious values proves to have a positive impact on individual tax compliance. Research on motivation to donate in Kuala Lumpur Malaysia found religious belief was a moderator that strengthens motivation to donate (Teah, Lwin, \& Cheah, 2014). The reason because it is essential for individuals with strong religious belief to provide a signal in the form of action, where the action is in line with the religious doctrine that they believe. Multi-cultural and multi-racial in Malaysia has a holistic approach to religious belief rather than specific religion (Loch et al., 2010). Research (Uyar et al., 2015) proves religiosity has a positive influence on ethical awareness. The main concept of all religions is to prevent people from immoral acts, always to uphold the truth, fair and not deceive, which ultimately leads people to follow the law (Uyar et al., 2015). The power of religiosity that is capable of mobilizing the people to obey taxes and form ethical individuals is an extraordinary power and can be used by the state to increase tax payments. Indonesia with six official religions is a society with a high culture of religiosity, such as Malaysia. If the religious commitment factor proves to be more dominant, then the government needs to approach the religious side to provide a tax-related understanding of religious education. This is still little that had been done by the government, although Indonesia has religious-based primary and secondary schools amounted to 48,354 Islamic-based schools (Indonesia Central Bureau of Statistics, 2015), not including other religions. The hypothesis of this research is

$\mathrm{H} 2$ : Religious commitment has a significant influence on individual satisfaction

H3: Religious commitment has a significant influence on tax morale

The research (Sá, Martins, \& Gomes, 2015) conducted in Portugal shows that there is no relation between religiosity and tax morale. Research (Welch et al., 2007), Mcgee (2012), 
Jalili (2012) show results where religiosity does not affect tax morale. This is because, in certain countries, religiosity is being seen as ethical or unethical, depending on how the state carries out all or part of the applicable religious law. If a country has a different view of ethical or unethical acts with any applicable religious law, then the society does not believe in any of the applicable religious law (as a standard of ethical or unethical behavior).

\subsection{Trust to Government Institutional, Individual Satisfaction, and Tax Morale}

Trust in institutional government is closely related to political stability, government effectiveness, regulatory quality, rules and policies, and corruption. If rules and policies are not formalized, the players spend a lot of time arguing about rules and policies, resulting in less time competing in productive activities (Ensley \& Munger, 2001 in Torgler, 2004b). High trust in government means government institutions can create a safe, stable, free from violence, justice, and individual satisfaction conditions. In this research, the taxpayer satisfaction indicator is measured by happiness and financial conditions.

Government institutions have an enormous role in improving tax compliance, especially in Indonesia, as Indonesian government is struggling to improve the image of government institutions, improving communication between government and society, and improving the transparency of state finances. These three are implemented in the form of eradicating corruption and simplifying licensing procedures across government agencies, multiplying call centers for public complaints, and building e-government based information technology. The government's credibility as a tax fund manager plays a significant role in improving the tax compliance of a country. (Picur \& Riahi-Belkaoui, 2006), which conducts cross-country research of 30 developed and developing countries, finds prevention of corruption and bloated bureaucracies increasing tax morale. This research finds tax compliance is highest in the countries that have high control corruption and low size of bureaucracy (Picur \& Riahi-Belkaoui, 2006). It is vital to protect the citizens from corruption and bureaucracy because it can build the perception or image regarding countries corruption and credibility of the bureaucracy, finally, threaten countries economic development. According to (Torgler, Schaffner \& Macintyre, 2007) if the interests of the taxpayers are represented by government institutions, and they enjoy good public facilities, then taxpayer compliance will increase. Responsive government results from a strong relationship between tax payments and the availability of good public facilities (Bird et al, 2004). In a low credibility government, party politicians, legislators, and administrative staff have great strength. This makes tax compliance from taxpayers lower. In a country where corruption occurs systematically and low financial transparency, it can not be assumed that paying taxes is an ethical and normative obligation. This means that in such conditions, a person who does not pay taxes, does not mean violate social norms, even taxpayers feel cheated (Torgler, Schaffner \& Macintyre, 2007). This result is also ongoing with Ibrahim, Musah \& Abdul-Hanan (2015) that trust in government is a crucial factor that drives tax morale. The research (Teah, Lwin \& Cheah, 2014) on donor institutional confidence, also proves that donating venues affect motivation to donate. Individual trust in international charity is higher than local charity because international charity is considered more efficient and better in distributing funds for the needy. This provides the view that in the case of tax payments, the credibility of state 
institutions as tax managers contributes substantially to tax compliance. State institutions perceived as clean, transparent and efficient will motivate taxpayers to be more compliant with paying taxes.

H4: Trust in the government agency has a significant influence on individual satisfaction

H5: Trust in the government agency has a significant influence on tax morale

\subsection{Democratic System, Trust in Government, Individual Satisfaction, and Tax Morale}

The democratic system affects tax morale. Research (Torgler, 2005) in Switzerland found direct democratic rights to have a strong influence on tax morale. A country that values the opinions of its citizens gets more support from its citizens (Prinz, 2002 in Torgler 2005). A government committed to running a direct democracy means forcing itself to hold back its power, and to signal that taxpayers are responsible individuals. According to (Torgler, 2005) direct democracy also means the government does not ignore or assume taxpayers, uncomprehending voters. Democracy's indicators in Indonesia use five indicators, that is accountability, rotation of power, open political recruitment, general elections, and the fulfillment of basic rights (Gaffar, 2005). The reason for the use of these indicators is because the taxes we discuss only in the scope of income taxes that are managed by the central government. So this research tries to assess the perceptions of respondents about the democratic system in central government. The government signals that taxpayer preferences are noticed and implemented in government processes. The higher the level of taxpayer participation in the decision-making process, the stronger the occurrence of social contracts based on trust, the higher tax morale of taxpayers (Torgler, 2005).

In a country with a democratic government, citizens may exercise the right vote to vote for or not to elect a leader. Indonesia is a democratic country where citizens choose leaders in the central and presidential institutions, so the higher the taxpayer's assessment of the government's democratic system, the higher the trust in government institutional. Based on the explanation, the research hypothesis is

H6: the Democratic system has a significant influence on individual satisfaction

H7: the Democratic system has a significant influence on tax morale

H8: the Democratic system has a significant influence on trust in government

\subsection{Perception of Others, Individual Satisfaction, and Tax Morale}

According to Reisinger and Turner (1997), Indonesian culture is highly collectivistic and group-oriented. Indonesian culture is more emphasis on people, human relations, and family oriented. Friendship is determined by stable and long-term relationship. So for Indonesia people, community, togetherness, and sociability are seen as very important in social life. Indonesian personal relationship is inclusive. Solitude is perceived negatively (Reisinger and Turner, 1997). That is why the perception of the environment, including friends, family, colleagues strongly influence the views of taxpayers in Indonesia, including tax morale.

Some taxpayers have the same views with other individuals. But other taxpayers disagree with other people view. This affects individual satisfaction. This is the problem of many 


\section{Macrothink}

people who enter the community. They are required to obey the will of the group, and these things will affect individual satisfaction. Indonesia is the best practices to see the effect of other's perceptions of individual satisfaction and tax morale.

H9: Perception of other taxpayers has a significant influence on individual satisfaction

H10: Perception of other taxpayers has a significant influence on tax morale

\subsection{Religious Commitment and Trust in Government}

Research of Poppe (1996) stated that religious leader could influence how the church's member view government. He also said that trust in the government is more likely if the church's membership is religiously active. His research proved that individuals who have a high level of religious behaviour are more likely to trust in the government than others (Poppe, 1996). The research hypothesis is

H11: Religious commitment has a significant influence on trust in government

\section{Research Methodology}

This research modified model uses in (Sá, Martins \& Gomes, 2015) research to adjust to conditions in Indonesia. Indicators and relationships among variables have been modified to suit the conditions in Indonesia. This study also compared answers from two groups of respondents, i.e., tax consultants and contractors.

\subsection{Method of Collecting Data}

In this study, the data collection was obtained from a direct survey to the taxpayers using a questionnaire. Data collection is done in two ways, by email or directly meet the taxpayers and then provide a questionnaire and conduct interviews. The statistical method used to test the validity and reliability test, a goodness of fit, and hypothesis test is Partial Least Square-SEM with the help of Wrap PLS program. This research does not use a different t-test to compare the answer of tax consultants and contractors because a few questions in the questionnaire are specific for each group of the respondent. Otherwise, we used descriptive analysis. Table 1 shows the variable indicators in this study. 
Table 1. Variable Indicators

\begin{tabular}{|c|c|c|}
\hline Variable & Indicators & References \\
\hline Democratic System & $\begin{array}{ll}\text { a. } & \text { accountability; } \\
\text { b. } & \text { rotation of power; } \\
\text { c. open political recruitment; } \\
\text { d. general election; } \\
\text { e. fulfillment of basic rights. }\end{array}$ & Gaffar (2005) \\
\hline $\begin{array}{l}\text { Religious } \\
\text { Commitment }\end{array}$ & $\begin{array}{l}\text { a. frequency of attendance to place of worship } \\
\text { (attendance); } \\
\text { b. liveliness in places of worship or activity of } \\
\text { religion (active); } \\
\text { c. religious education (education); } \\
\text { d. become religious (being religiosity); } \\
\text { e. the importance of religion in life (importance) } \\
\text { f. guidance; } \\
\text { g. trust in a place of worship (trust) }\end{array}$ & Torgler (2007) \\
\hline $\begin{array}{l}\text { Perception } \\
\text { others }\end{array}$ & $\begin{array}{l}\text { a. The majority of known persons do not fill SPT } \\
\text { clearly, correctly and completely; } \\
\text { b. The majority of known persons do not perform } \\
\text { bookkeeping and listing obligations, including } \\
\text { the obligation to show or lend books, records, } \\
\text { and other documents. } \\
\text { c. The majority of known persons do not deposit } \\
\text { any withholding or withholding taxes; } \\
\text { d. The majority of known persons do not register, } \\
\text { abuse or use without the right of the Taxpayer } \\
\text { Identification Number (NPWP); } \\
\text { e. The majority of people known to bribe tax } \\
\text { authorities and / or other intimidating acts. }\end{array}$ & Torgler (2003) \\
\hline $\begin{array}{l}\text { Individual } \\
\text { Satisfaction }\end{array}$ & $\begin{array}{l}\text { a. The level of individual satisfaction over the } \\
\text { financial condition for this. } \\
\text { b. The level of individual happiness over the } \\
\text { years. }\end{array}$ & Torgler (2004a) \\
\hline $\begin{array}{l}\text { Trust in } \\
\text { government agency }\end{array}$ & $\begin{array}{l}\text { a. Political Stability and Absence of Violence, } \\
\text { b. Government Effectiveness, } \\
\text { c. Regulatory Quality, } \\
\text { d. Rule of Law, } \\
\text { e. Control of Corruption. }\end{array}$ & $\begin{array}{l}\text { Kauffman, Kraay, } \\
\& \quad \text { Mastruzzi } \\
(2009)\end{array}$ \\
\hline Tax Morale & $\begin{array}{l}\text { a. Not cheating on tax payments despite the } \\
\text { opportunity. } \\
\text { b. Tax management to save tax payments is not } \\
\text { true. } \\
\text { c. Guilt if not reporting all income to reduce the } \\
\text { amount of tax payment. }\end{array}$ & Torgler (2011) \\
\hline
\end{tabular}

The measurement scale for democratic system variables, religiosity, environmental perception, trust in government institutions, and tax morale, using a 4-point scale with a score of 1 "Strongly Disagree", a score of 2 "Disagree", a score of 3 "Agree", a score of 4 "Strongly Agree ". Interpretation of respondents' answers are divided into the following 3 groups: 
Table 2. Variable Indicators

\begin{tabular}{c|c}
\hline Average Value & Interpretation \\
\hline $1-2,3$ & Low \\
$2,31-3,6$ & High \\
$3,61-4$ & Very High \\
\hline
\end{tabular}

\subsection{Sample Determination}

The population in this study consists of two groups, that is taxpayers who work as tax consultants and contractors. Sampling technique used in this research is purposive sampling with certain criteria:

a. Tax consultant with the following criteria:

1. Individual taxpayers who work as tax consultants,

2. Incorporated in IKPI organization membership,

3. Has worked as a tax consultant for at least one year

b. Contractors with the following criteria:

1. Individual taxpayer who owns contractions business,

2. Having an office as a business representative,

3. Has worked as contractors for at least one year

The minimum sample size is calculated as ten times the number of variables in the research model. There are 6 variables in this study so that the minimum sample size as much as $10 \times 6$ variables $=60$ respondents. The number of respondents in this study was 60 respondents of tax consultants and 78 respondents of contractors.

\section{Results and Discussion}

\subsection{Description of Respondents}

Description of respondent's profile include age, gender, religion, marital status, last education, and annual income, in this study which will be described in the table 3 below: 
Table 3. Description of Respondents

\begin{tabular}{|c|c|c|c|c|c|}
\hline \multirow[t]{2}{*}{ Characteristics } & \multirow[t]{2}{*}{ Category } & \multirow{2}{*}{$\begin{array}{c}\text { Tax } \\
\text { Consultant } \\
\text { Frequency } \\
\end{array}$} & \multirow{2}{*}{$\begin{array}{c}\text { Contractors } \\
\text { Frequency }\end{array}$} & \multicolumn{2}{|c|}{ Totals } \\
\hline & & & & Frequency & Percentage \\
\hline \multirow[t]{3}{*}{ Umur } & $22-29$ & 10 & 11 & 21 & $15.2 \%$ \\
\hline & $30-49$ & 42 & 48 & 90 & $65.2 \%$ \\
\hline & $50-64$ & 8 & 19 & 27 & $19.6 \%$ \\
\hline \multirow[t]{2}{*}{ Gender } & Wanita & 43 & 50 & 93 & $67.4 \%$ \\
\hline & Pria & 17 & 28 & 45 & $32.6 \%$ \\
\hline \multirow[t]{6}{*}{ Religion } & Catholic & 22 & 10 & 32 & $23.2 \%$ \\
\hline & Islam & 15 & 30 & 45 & $32.6 \%$ \\
\hline & Christian & 17 & 33 & 50 & $36.2 \%$ \\
\hline & Buddha & 5 & 4 & 9 & $6.5 \%$ \\
\hline & Confucian & 1 & 1 & 2 & $1.4 \%$ \\
\hline & Hindu & 0 & 0 & 0 & $0.0 \%$ \\
\hline \multirow[t]{3}{*}{ Marital Status } & Single & 49 & 32 & 81 & $58.7 \%$ \\
\hline & Married & 11 & 46 & 57 & $41.3 \%$ \\
\hline & Divorced/Widowed & 0 & 0 & 0 & $0.0 \%$ \\
\hline \multirow{5}{*}{$\begin{array}{l}\text { Highest Level of } \\
\text { Education }\end{array}$} & & & & & \\
\hline & College & 0 & 0 & 0 & $0.0 \%$ \\
\hline & Bachelor Degree & 39 & 56 & 95 & $68.8 \%$ \\
\hline & Postgraduate Degree & 21 & 21 & 42 & $30.4 \%$ \\
\hline & Doctorate Degree & 0 & 1 & 1 & $0.7 \%$ \\
\hline \multirow[t]{4}{*}{ Annual Income } & below Rp 50 millions & 12 & 6 & 18 & $13.0 \%$ \\
\hline & Rp 50 - 250 millions & 26 & 42 & 68 & $49.3 \%$ \\
\hline & Rp 250 - 500 millions & 19 & 25 & 44 & $31.9 \%$ \\
\hline & above Rp 500 million & 3 & 5 & 8 & $5.8 \%$ \\
\hline \multicolumn{2}{|c|}{ Number of Respondents } & 60 & 78 & 138 & $100.0 \%$ \\
\hline
\end{tabular}

Based on table 3, most respondents aged 30 - 49 years are about $65.2 \%$. The number of female respondents is greater than men, amounting to $67.4 \%$ of women. Christian and Islam are the largest religion of respondents, approximately $36.2 \%$ and $32.6 \%$. This research succeeded in collecting data of respondents from various religions, except Hindu who adheres a little in the city of Surabaya. The marital status of the respondents is dominated by single around $58.7 \%$. The last education majority is bachelor degree which is $68.8 \%$. The most dominant income per year is between Rp 50 - 250 million, which is $49.3 \%$.

Table 4. Description of Average Respondents Answer

\begin{tabular}{l|c|c}
\hline \multicolumn{1}{c|}{ Variables } & Tax Consultant & Contractors \\
\hline Religious Commitment & 3,22 & 3,05 \\
Trust in Government & 2,37 & 2,52 \\
Democratic System & 2,84 & 3,06 \\
Perception of Others & 1,64 & 2,89 \\
Taxpayer Satisfaction & 3,62 & 3,13 \\
Tax Morale & 3,17 & 2,89 \\
\hline
\end{tabular}


Table 4 above shows the religious perceptions of tax consultants and contractors including high category (above 2.31). This means that both groups of respondents have a high religious commitment, both from intrapersonal religious commitment and interpersonal religious commitment. The average respondent's answer to trust in government variables is high but almost close to the lower limit of 2.31. Respondent's answer to democratise system variable also belongs to a high category. The dependence of the respondents on the perception of other taxpayers is a high category for the group of contractors, but it is a low category for tax consultants. This is happening because tax consultants are more aware of the rules and tax policies, so it is more independent than the construction businessman. Regarding individual satisfaction, tax consultants and contractors are categorized as very high and high. This shows the level of tax consultant satisfaction is higher than the construction businessman. In the case of tax morale, the responses of both groups of respondents are high, but the tax consultant is slightly higher than the construction businessman.

\subsection{Analysis Partial Least Square}

Table 5. Model Fit and Quality Indices for Tax Consultant and Contractors Models

\begin{tabular}{|c|c|c|c|}
\hline Model Fit and Quality Indices & Criterion Fit & Tax Consultants & Contractors \\
\hline Average path coefficient (APC) & $\mathrm{p}<0.05$ & $\mathrm{P}=0.006$ & $\mathrm{P}=0.017$ \\
\hline Average R-squared (ARS) & $p<0.05$ & $\mathrm{P}<0.001$ & $\mathrm{P}=0.003$ \\
\hline Average adjusted R-squared (AARS) & $\mathrm{p}<0.05$ & $\mathrm{P}<0.001$ & $\mathrm{P}=0.006$ \\
\hline Average block VIF (AVIF) & $\begin{array}{l}\text { Acceptable if }<=5, \\
\text { ideally }<=3.3\end{array}$ & 1.549 & 1.802 \\
\hline $\begin{array}{llll}\begin{array}{l}\text { Average } \\
\text { (AFVIF) }\end{array} & \text { full } & \text { collinearity } & \text { VIF } \\
\end{array}$ & $\begin{array}{l}\text { Acceptable if }<=5, \\
\text { ideally }<=3.3\end{array}$ & 1.666 & 1.613 \\
\hline Tenenhaus GoF (GoF) & $\begin{array}{lrr}\text { Small }>= & 0.1, \\
\text { medium }>= & 0.25, \\
\text { large }>=0.36 & \end{array}$ & 0.561 & 0.412 \\
\hline Sympson's paradox ratio (SPR) & $\begin{array}{l}\text { Acceptable if }>=0.7 \text {, } \\
\text { ideally }=1\end{array}$ & 0.909 & 0.818 \\
\hline R-squared contribution ratio (RSCR) & $\begin{array}{l}\text { Acceptable if }>=0.9 \text {, } \\
\text { ideally }=1\end{array}$ & 0.967 & 0.899 \\
\hline Statistical suppression ratio (SSR) & Acceptable if $>=0.7$ & 1.000 & 1.000 \\
\hline $\begin{array}{l}\text { Nonlinear bivariate causality direction } \\
\text { ratio (NLBCDR) }\end{array}$ & Acceptable if $>=0.7$ & 1.000 & 0.818 \\
\hline
\end{tabular}

The result of the goodness of fit tax consultant and contractor model shows that both have met the criteria, so it can be said that both models have been compatible and supported by the data.

Table 6. R-square Coefficients

\begin{tabular}{l|c|c}
\hline \multicolumn{1}{c|}{ Laten Variables } & Tax Consultants & Contractors \\
\hline TrustGov & 0,488 & 0,018 \\
TpSatis & 0,452 & 0,263 \\
TpMorale & 0,532 & 0,541 \\
\hline
\end{tabular}


Table 6 shows the tax consultant model can explain $48.8 \%$ predictors affecting trust in the government, while contractors model is only able to explain $1.8 \%$. The tax consultant model can explain $45.2 \%$ of predictors affecting taxpayer satisfaction, but the construction model can only explain $26.3 \%$. Both models succeeded in explaining the predictor of tax morale, in which both R-squares show the values of $53.2 \%$ and $54.1 \%$.

Table 7. Path Coefficients and P-value for Direct Effect

\begin{tabular}{|c|c|c|c|c|c|c|}
\hline \multirow[b]{2}{*}{ Direct Effect } & \multicolumn{3}{|c|}{ Tax Consultants } & \multicolumn{3}{|c|}{ Contractors } \\
\hline & Coefficient & P-Value & $\begin{array}{l}\text { Result of } \\
\text { hypothesis } \\
\text { testing }\end{array}$ & Coefficient & P-Value & $\begin{array}{l}\text { Result of } \\
\text { hypothesis } \\
\text { testing }\end{array}$ \\
\hline ReligCo $\rightarrow$ TpSatis & 0,566 & $<0,001 *$ & H2 accepted & $-0,154$ & 0,078 & $\mathrm{H} 2$ rejected \\
\hline DemocSys $\rightarrow$ TpSatisf & 0,183 & 0,068 & H6 rejected & 0,412 & $<0,001 *$ & H6 accepted \\
\hline TrustGov $\rightarrow$ TpSatisf & 0,283 & $0,009 *$ & H4 accepted & $-0,164$ & 0,066 & H4 rejected \\
\hline PercpOt $\rightarrow$ TpSatisf & 0,166 & 0,088 & H9 rejected & 0,114 & 0,150 & H9 rejected \\
\hline ReligCo $\rightarrow$ TpMorale & 0,160 & 0,097 & $\mathrm{H} 3$ rejected & 0,371 & $<0,001 *$ & H3 accepted \\
\hline DemocSys $\rightarrow$ TpMorale & 0,289 & $0,008^{*}$ & H7 accepted & 0,241 & $0,012 *$ & H7 accepted \\
\hline TrustGov $\rightarrow$ TpMorale & 0,058 & 0,323 & H5 rejected & $-0,076$ & 0,247 & H5 rejected \\
\hline PercpOt $\rightarrow$ TpMorale & $-0,202$ & $0,049 *$ & H10 accepted & 0,180 & $0,048^{*}$ & H10 accepted \\
\hline Tpsatisf $\rightarrow$ TpMorale & 0,329 & $0,003 *$ & H1 accepted & 0,045 & 0,343 & $\mathrm{H} 1$ rejected \\
\hline ReligCo $\rightarrow$ TrustGo & 0,091 & 0,235 & H11 rejected & 0,190 & $0,039 *$ & H11 accepted \\
\hline DemocSys $\rightarrow$ TrustGov & 0,658 & $<0,001 *$ & H8 accepted & 0,234 & $0,015^{*}$ & H8 accepted \\
\hline
\end{tabular}

*Significant at $5 \%$

Table 8. Effect Size for Path Coefficient

\begin{tabular}{l|l|l}
\hline \multicolumn{1}{c|}{ Direct Effect } & \multicolumn{1}{c|}{$\begin{array}{c}\text { Tax } \\
\text { Consultants }\end{array}$} & \multicolumn{1}{c}{ Contractors } \\
\hline ReligCo $\rightarrow$ TpSatis & 0,36 (strong) & - \\
DemocSys $\rightarrow$ TpSatisf & - & 0,23 (medium) \\
TrustGov $\rightarrow$ TpSatisf & 0,10 (weak) & - \\
PercpOt $\rightarrow$ TpSatisf & - & - \\
\hline ReligCo $\rightarrow$ TpMorale & - & 0,25 (medium) \\
DemocSys $\rightarrow$ TpMorale & 0,15 (medium) & 0,15 (medium) \\
TrustGov $\rightarrow$ TpMorale & - & - \\
PercpOt $\rightarrow$ TpMorale & 0,08 (weak) & 0,11 (weak) \\
Tpsatisf $\rightarrow$ TpMorale & 0,19 (medium) & - \\
\hline ReligCo $\rightarrow$ TrustGo & - & 0,04 (weak) \\
DemocSys $\rightarrow$ TrustGov & 0,46 (strong) & 0,06 (weak) \\
\hline
\end{tabular}

Criterion: weak $(0,02)$, medium $(0,15)$, dan strong $(0,35)$

The following interpretation of tables 7 and 8 that is: the results of the tax consultant model show taxpayer satisfaction and democratic system is a predictor of the strongest influence on tax morale. This can be seen from the coefficient of 0.329 and 0.289 . From the contractor, religious commitment and democratic system is the strongest predictor affecting tax morale, with coefficient 0,371 and 0,241 . According to the tax consultant, religious commitments have the strongest influence on taxpayer satisfaction, whereas according to the contractors, democratic has the most powerful influence. Predictors affecting trust in government, both 
groups of respondents agree that the democratic system is the strongest influence than the other predictors.

Table 9. P-value for Indirect Effect

\begin{tabular}{|c|c|c|c|c|c|}
\hline \multirow{2}{*}{\multicolumn{2}{|c|}{ Indirect Effect }} & \multicolumn{2}{|c|}{ Tax Consultants } & \multicolumn{2}{|c|}{ Contractors } \\
\hline & & P-Value & Conclusion & P-Value & Conclusion \\
\hline $\begin{array}{l}\text { ReligCo } \\
\text { TpMorale }\end{array} \quad \rightarrow \quad$ TpSatis & & 0,059 & Not Significant & 0,425 & Not Significant \\
\hline $\begin{array}{l}\text { DemocSys } \rightarrow \text { TpSatis } \\
\text { TpMorale }\end{array}$ & & 0,216 & Not Significant & 0,373 & Not Significant \\
\hline $\begin{array}{l}\text { TrustGov } \quad \rightarrow \quad \text { TpSatis } \\
\text { TpMorale }\end{array}$ & $\rightarrow$ & 0,148 & Not Significant & 0,463 & Not Significant \\
\hline $\begin{array}{l}\text { PercpOth } \rightarrow \text { TpSatis } \\
\text { TpMorale }\end{array}$ & $\rightarrow$ & 0,272 & Not Significant & 0,474 & Not Significant \\
\hline $\begin{array}{l}\text { ReligCo } \\
\text { TpSatisf }\end{array} \rightarrow$ TrustGov & $\rightarrow$ & 0,388 & Not Significant & 0,348 & Not Significant \\
\hline $\begin{array}{l}\text { DemocSys } \rightarrow \text { TrustGov } \\
\text { TpSatisf }\end{array}$ & $\rightarrow$ & 0,017 & Significant & 0,315 & Not Significant \\
\hline
\end{tabular}

Table 9 shows that trust in government is the only variables that proved to be the mediating variable between the democratic system and taxpayer satisfaction in the tax consultant model. However, this relationship is not significant in the contractors model.

The cross-loading results of both models show the outer model meets the convergent validity. Similarly, the composite reliability coefficients of both models have met the criteria (table 10). Cronbach's alpha coefficients tax consultant and construction model meet the criteria (table 11). Discriminant validity for all variables in both models has been met. The collinearity test among the predictor variables also meets the VIF criteria <10 (table 12).

Table 10. Composite Reliability Coefficients

\begin{tabular}{l|c|c}
\hline \multicolumn{1}{c|}{ Variabel Laten } & $\begin{array}{c}\text { Tax Consultant } \\
\text { Model }\end{array}$ & $\begin{array}{c}\text { Contractors } \\
\text { Model }\end{array}$ \\
\hline ReligCom & 0,849 & 0,899 \\
DemocSys & 0,853 & 0,885 \\
TrustGov & 0,946 & 0,915 \\
PercpOth & 0,940 & 0,842 \\
TpSatisf & 0,954 & 0,954 \\
TpMorale & 0,931 & 0,875 \\
\hline
\end{tabular}

Criterion: Composite reliability coefficients $>0,7$

Table 11. Cronbach's alpha coefficients

\begin{tabular}{l|c|c}
\hline \multicolumn{1}{c|}{ Variabel Laten } & $\begin{array}{c}\text { Tax Consultant } \\
\text { Model }\end{array}$ & $\begin{array}{c}\text { Contractors } \\
\text { Model }\end{array}$ \\
\hline ReligCom & 0,788 & 0,857 \\
DemocSys & 0,796 & 0,837 \\
TrustGov & 0,937 & 0,895 \\
PercpOth & 0,919 & 0,747 \\
TpSatisf & 0,936 & 0,935 \\
TpMorale & 0,906 & 0,831 \\
\hline
\end{tabular}


Criterion: Cronbach's alpha coefficients > 0,6

Table 12. Collinearity test among the predictor variables

\begin{tabular}{l|c|c}
\hline \multicolumn{1}{c|}{ Direct Effect } & $\begin{array}{c}\text { Tax Consultant } \\
\text { Model }\end{array}$ & $\begin{array}{c}\text { Contractors } \\
\text { Model }\end{array}$ \\
\hline ReligCo $\rightarrow$ TrustGo & 1,176 & 1,004 \\
ReligCo $\rightarrow$ TpSatis & 1,147 & 1,938 \\
ReligCo $\rightarrow$ TpMorale & 2,066 & 3,702 \\
DemocSys $\rightarrow$ TrustGov & 1,176 & 1,004 \\
DemocSys $\rightarrow$ TpSatisf & 2,071 & 1,322 \\
DemocSys $\rightarrow$ TpMorale & 1,533 & 2,300 \\
TrustGov $\rightarrow$ TpSatisf & 2,014 & 1,069 \\
TrustGov $\rightarrow$ TpMorale & 1,579 & 1,078 \\
PercpOt $\rightarrow$ TpSatisf & 1,121 & 1,956 \\
PercpOt $\rightarrow$ TpMorale & 1,166 & 3,175 \\
Tpsatisf $\rightarrow$ TpMorale & 1,987 & 1,269 \\
\hline
\end{tabular}

Criterion: VIF $<10$

\subsection{Discussion}

Based on the test results, tax consultant respondents consider the dominant factor affecting tax morale is individual satisfaction. In contrast to the perception of contractors where according to them, individual satisfaction does not affect tax morale. Differences in perceptions between these two groups of respondents can be analyzed from various causes such as construction business services tend to be more volatile than the services of tax consultants. Although this research is done when the financial condition of contractors is rising, due to the fluctuations in business income, according to them tax satisfaction is not related to tax morale. According to the buffer-stock theory of Carroll (1992), discloses consumers withhold their assets as reserves in the event of earning's fluctuations in the future that can not be predicted. In the case of tax morale, when business income is more volatile, the business climate is unstable (e.g., government rules and policies change rapidly), the tax morale tends to be lower, because the asset reserves they have to prepare when the business is decreasing. When this study was conducted, the Indonesian government had suspended professional license of tax consultants for 2 years, so during that time there was no new license for the new tax consultant. Along with the implementation of tax law enforcement, causing demand for tax consulting services higher than other periods. This causes tax consultant services tend to be more stable than contractors. The second cause is the tax consultant believes with the perception that taxpayers with a better financial condition should pay bigger taxes. In contrast to contractors who argue that income is greater due to harder business, so it is heavier to pay taxes. The research of Kawulusan and Tjondro (2016) in Indonesia that examines the influence of 'how hard the taxpayers work' to the perception of tax evasion, shows the results of taxpayers who assess that they work very hard, increasingly agree with the tax evasion action. 
This study found the democratic system proved to affect tax morale with medium effect size from tax consultants and contractors. According to Torgler (2005), the government signaled that taxpayer preferences are noticed and implemented in the governance process. The higher the level of taxpayer participation in the decision-making process, the stronger the occurrence of social contracts based on trust, the higher tax morale of taxpayers (Torgler, 2005). According to Torgler (2004b), the active role of democratic citizens helps the State to monitor and control politicians and thereby reduce the information gap and reduce the inflexibility of government power. The democratic system may represent the opinion of taxpayers for the government of the State. A democratic system of government opens opportunities for citizens in expressing their views (Torgler, 2004a). This explanation is also supported by the average responses of both groups of respondents who are categorized as high for the democratic system factor in Indonesia (Table 1).

Table 13. Average Respondent's Answer

\begin{tabular}{c|c|c}
\hline Variable & Tax Consultant & Contractors \\
\hline Democratic System & 2,84 out of 4 & 2,92 out of 4 \\
\hline
\end{tabular}

Trust in the government proved not to affect tax morale according to both groups of respondents. Average respondent's answer for trust to the government variable tends to be low, both from tax consultants and contractors, but from the tax morale side, both groups of respondent's answer tend to be high. This can be seen in the following table:

Table 14. Average Respondent's Answer

\begin{tabular}{l|c|c}
\hline \multicolumn{1}{c|}{ Variable } & Tax Consultant & Contractors \\
\hline $\begin{array}{l}\text { Trust to Institutional } \\
\text { Government }\end{array}$ & 2,3 out of 4 & 2,5 out of 4 \\
\hline Tax Morale & 3,2 out of 4 & 2,9 out of 4 \\
\hline
\end{tabular}

In Indonesia, trust to institutional government does not affect tax morale because it is common practice in Indonesian society that taxpayers are "just paying taxes", do not see whether the nominal is paid following the actual circumstances. The only important thing is they already paid the taxes. What's going on when the tax officer checked the payment? A bribe was common in the past years, and the nominal was not high. I think the society needs more time to change their mind to pay the real taxes. This result is also supported by a survey conducted by the OECD (2013) in Indonesia on "do you agree if you can see government expenditures, even if they result in tax increases?". The average answer is 3.7 on a scale of 1 5 , meaning the respondent's answer in the $2-3$ score range. This shows that some respondents disagree if there is a tax increase despite an increase in government expenditure transparency. The culture of "just paying taxes" is stronger than feelings importance of transparency and trust in institutional government. Trust in institutional government does not affect tax morale under conditions in countries where tax rules are not applied strictly for long periods of time. The new mass tax enforcement is enforced through the signing of the cooperation between the Directorate General of Taxation and the Indonesia National Police in 2014. According to Joulfaian (2009), there are several conditions that caused tax evasion to develop, that is (1) when the bribe to tax officers became general habits, (2) lack of sufficient reward on the ability of tax officers to detect tax evasion by taxpayers. However, Akdede (2006) states that 
if the nominal bribe is large, then the taxpayer will choose to pay taxes rather than tax evasion. This means there is a way to increase the value of bribe: (1) increasing the probability of detection by higher inspectors, (2) increasing penalty value for both parties involved bribe (Akdede, 2006).

Perception of others proved to affect tax morale but with weak effect size, both from the perception of tax consultants and contractors. This suggests that people in big cities no longer rely on information from other taxpayer, but they are more aware of the importance of this tax problem, preferring to seek information from a tax expert. In addition, easy access to information in large cities helped reduce the dominance of this variable to tax morale.

The interesting fact in this research is that religious commitment is the dominant factor affecting tax morale from the perception of contractors. This means they voluntarily pay taxes because they obey social norms, uphold the truth, fair, and not cheat. In this case, the power of religiosity is able to move contractors to pay taxes obediently. This result is supported by research (Mohdali \& Pope, 2014) in Malaysia, which found religious commitment has a positive effect on tax morale. The results of this study is consistent with the research of Torgler (2007), proving that there is a negative correlation between religious membership and crime. The results of the study is also consistent with Adam Smith's argument (Smith, 2010) in his Theory of Moral Sentiments, concludes that religiosity acts as a mechanism driving human's moral self. Instead, this study found for tax consultants, religious commitment does not affect tax morale.

The dominant factor affect individual satisfaction according to tax consultant is a religious commitment, with effect size 0.36 which is included in a strong category. Based on the results of this research we can conclude religious commitment of tax consultants is stronger influence on individual satisfaction than tax morale. Okulicz-Kozaryn (2010) found that the form of religiosity is promoting social capital which is predicted to produce high individual satisfaction. Religiosity accommodates "need to belong" feelings one expected, thus increasing the individual taxpayer's satisfaction.

\section{Conclusions and Recommendations}

Tax consultants and contractors have different views on factors affecting tax morale. The perception of tax morale from the perspective of the tax consultant is dominantly influenced by individual satisfaction and democratic system, while from the point of view of the construction entrepreneur the factor of religious commitment and democratic system tend to be more dominant. The fact that these two types of businesses have different business characteristics influences the different perceptions of both groups of respondents.

The democratic system proved to affect tax morale with medium level of influence, both from the perception of tax consultants and contractors. This provides an understanding that the two groups consider the government, as the policy maker, should involves the taxpayers. Democratic is closely related to the principles of learning and bottom-up approach (Papaioannou, 2007), so taxpayers expect taxation rules and policies that run is a contract or an agreement with the taxpayers. 
An interesting finding is that trust in institutional government does not affect the tax morale of both groups of respondents. Although both respondents have answers that are not much different, both groups agree that this trust of the government does not affect the tax morale. The practice of just paying taxes that happened in the past is one of the reasons. It takes time to force Indonesian taxpayers to pay the real taxes. This causes Indonesian government unable to increase the tax morale of Indonesian society.

Other taxpayers perception proved affecting tax morale, according to the two groups of taxpayers, but with a very small (weak) level of influence. This result proves that awareness about taxation is no longer dependent on the opinions or arguments of the surrounding environment (family, business associates, or friends). Taxpayers see the tax as an important factor affecting the business sustainability (sustainability effort), so more dependent on the opinion of experts in the field of taxation.

Suggestions for further research are more emphasis on surveys of democratic forms of the wider system, so taxpayers are involved in decision-making related taxation. In addition to further research on government institutions, it is important to consider which government institutions are dominant factors according to respondents' perceptions, i.e., events / events closest to the implementation of surveys that may affect perceptions of respondents.

\section{References}

Akdede, S. H. (2006). Corruption and tax evasion. Doğuş Üniversitesi Dergisi, 7(2), 141-149. Retrived from http://journal.dogus.edu.tr/index.php/duj/article/view/104/pdf_akdede

Bird, R., Martinez, V. J., \& Torgler, B. (2004). Societal institutions and tax effort in developing countries. CREMA Working Paper. https://doi.org/10.2139/ssrn.662081

Carroll, C. D. (1992). The buffer-stock theory of saving: some macro economic evidence. Brooking Papers on Economic Activity, 2. https://doi.org/10.2307/2534582

Finn, D. W., Chonko, L. B., \& Hunt, S. D. (1988). Ethical problems in public accounting: the view from the top. Journal of Business Ethics, 7, 605-615. https://doi.org/10.1007/BF00382793

Gaffar, A. (2005). Politik Indonesia, Transisi Menuju Demokrasi. Yogyakarta: Pustaka Pelajar.

Gintis, H., Henrich, J., Bowles, S., Boyd, R., \& Fehr, E. (2008). Strong reciprocity and the roots of human morality. Social Justice Research 21, 241-253. https://doi.org/10.1007/s11211-008-0067-y

Ibrahim, M., Musah, A., \& Abdul, H. A. (2015). Beyond enforcement: what drives tax morale in Ghana? Humanomics, 31(4), 399-414. https://doi.org/10.1108/H-04-2015-0023

Indonesia Central Bureau of Statistics. (2015). Number of schools, teachers, and students of madrasah tsanawiyah (MTs) under the Ministry of Religious Affairs by province of 2011 / 2012-2014 / 2015 academic year. Retrieved from https://www.bps.go.id/statictable 
Indonesia Tax Consultant Organization. (2014). Anggaran Dasar, Anggaran Rumah Tangga, Kode Etik, Standar Profesi Konsultan Pajak.

Jalili, A. R. (2012). The Ethics of Tax Evasion: An Islamic Perspective. https://doi.org/10.1007/978-1-4614-1287-8_11

Joulfaian, D. (2009). Bribes and business tax evasion. European Journal of Comparative Economics, 6(2), 227-244. Retrieved from http://eaces.liuc.it/18242979200902/182429792009060203.pdf

Kaufmann, D., Kraay, A., \& Mastruzzi, M. (2009). Governance Matters VIII: Aggregate and Individual Governance Indicators. Policy Research Working Paper 4978. https://doi.org/10.1596/1813-9450-4978

Kawulusan, J., \& Tjondro, E. (2016). Pengaruh faktor demografis terhadap tax Evasion. Unpublished paper.

Leung, P., \& Cooper, B. J. (1995). Ethical dilemmas in accountancy practice. Australian Accountant, 65(4), 28-33.

Loch, A., Hilmi, I. N., Mazam, Z., Pillay, Y., \& Choon, D. S. K. (2010). Differences in attitude towards cadaveric organ donation: observations in a multiracial Malaysian society. Hong Kong Journal of Emergency Medicine, 17(3), 236-243. https://doi.org/10.1177/102490791001700306

McGee, R. W. (2012). Christian views on the ethics of tax evasion, in McGee, R.W. (Ed), The Ethics of Tax Evasion: Perspectives in Theory and Practice (pp. 201-210). https://doi.org/10.2139/ssrn.461398

Mohdali, R., \& Pope, J. (2014). The influence of religiosity on taxpayers compliance attitudes. Accounting Research Journal, 27(1), 71-91. https://doi.org/10.1108/ARJ-08-2013-0061

OECD. (2013). What drives tax morale. Retrieved Desember 4, 2017, from www.oecd.org/ctp/tax-global/what-drives-tax-morale.pdf

Office Staf President. (2015). Meningkatkan Kualitas Hidup Manusia Indonesia. http://ksp.go.id/meningkatkan-kualitas-hidup-manusia-indonesia/

Okulicz, K. A. (2010). Religiosity and life satisfaction across nations. Mental Health, Religion \& Culture, 13(2), 155-169. https://doi.org/10.1080/13674670903273801

Papaioannou, T. (2007). Policy benchmarking: a tool of democracy or a tool of authoritarianism? Benchmarking: An International Journal, 14(4), 497-516. https://doi.org/10.1108/14635770710761898

Picur, R. D., \& Riahi, B. A. (2006). The impact of bureaucracy, corruption and tax compliance. Review of Accounting and Finance, 5(2), 174-180. https://doi.org/10.1108/14757700610668985 
Pope, J., \& Mohdali, R. (2010). The role of religiosity in tax morale and tax compliance. Australian Tax Forum, 25(4), 565-596. Retrieved from https://www.researchgate.net/profile/Nor_Mohd_Ali3/publication/290920060_The_role_of_r eligiosity_in_tax_morale_and_tax_compliance/links/569c9b6d08aea1476954fc89.pdf

Poppe, J. (1996). Political trust and religion. Wisconsin Lutheran College, USA. Retrieved frm https://pdfs.semanticscholar.org/a48a/3b99970ed7a7578cb00acf6cfbdbb3a53181.pdf

Regulation of Finance Minister No 111/PMK.03/2014 tax consultants

Reisinger, Y., \& Turner, L. (1997). Cross-cultural Differences in Tourism: Indonesian Tourist in Australia. Tourism Management, $\quad 18(3), \quad 139 \quad$ - $\quad 147$. https://doi.org/10.1016/S0261-5177(96)00115-X

Sá, C., Martins, A., \& Gomes, C. (2015). Tax morale determinants in Portugal. European Scientific Journal, 11(10), 236. Retrieved from https://www.eujournal.org

Smith, A. (2010). The theory of moral sentiments. https://doi.org/10.1002/9781118011690.ch10

Teah, M., Lwin, M., \& Cheah, I. (2014). Moderating role of religious beliefs on attitudes towards charities and motivation to donate. Asia Pacific Journal of Marketing and Logistics, 26(5), 738-760. https://doi.org/10.1108/APJML-09-2014-0141

Torgler, B. (2005). Tax morale in latin america. Public Choice, 122 (1/2), 133-157. Springer. https://www.jstor.org/stable/pdf/30026676.pdf? refreqid=excelsior\%3Adca41d1ce1379eOfcbe $d b 3 e 348 b 376 d 6$

Torgler, B. (2003). Theory and Empirical Analysis of Tax Compliance. Universität Basel, Switzerland.

Torgler, B. (2004a). Tax Morale in Asian Countries. Center for Research in Economics, Management, and the Arts (CREMA). University of Basel, WWZ, Switzerland. Retrieved August 2, 2017, from https://pdfs.semanticscholar.org/d005/85d9694eafd178091b3a1f3674dd3361733e.pdf?_ga=2. 103009416.946349418.1524728737-2129951914.1495698571

Torgler, B. (2004b). Tax Morale, Trust and Corruption: Empirical Evidence from Transition Countries. Center for Research in Economics, Management, and the Arts (CREMA). University of Basel, WWZ, Switzerland. Retrieved August 10, 2017, from http://m.crema-research.ch/papers/2004-05.pdf

Torgler, B. (2005). Tax morale and direct democracy. European Journal of Political Economy, 21(2), 525-531. https://doi.org/10.1016/j.ejpoleco.2004.08.002

Torgler, B., Schaffner, M., \& Macintyre, A. (2007). Tax Compliance, Tax Morale, and Governance Quality. International Studies Program Working Paper, (No. 2007-17). www.crema-research.ch/papers/2007-17.pdf

Torgler, B. (2007). Tax Compliance and tax morale: a theoretical and empirical analysis. 


\section{Macrothink}

Edward Elgar: USA. https://doi.org/10.4337/9781847207203

Torgler, B. (2011). Tax Morale and Compliance: Review of Evidence and Case Studies for Europe. Policy Research Working Paper 5922, The World Bank, Washington DC. https://doi.org/10.1596/1813-9450-5922

United Nation Development Program. (2016). Human Development Report 2016, Human Development for Everyone

Uyar, A., Kuzey, C., Güngörmüs, A. H., \& Alas, R. (2015). Influence of theory, seniority, and religiosity on the ethical awareness of accountants. Social Responsibility Journal, 11(3), 590-604. https://doi.org/10.1108/SRJ-06-2014-0073

Welch, M. R., Xu, Y., Bjarnason, T., Petee, T., Donnell, P. O., \& Magro, P. (2007). "But Everybody Does It...": The Effects Of Perceptions, Moral Pressures, And Informal Sanctions On Tax Cheating. Sociological Spectrum : Mid-South Sociological Association, 25, 21-52. https://doi.org/10.1080/027321790500103

Wibowo, H. P. (2014). Naik $27 \%$ penerimaan pajak Surabaya tertinggi di Indonesia. Retrieved from September, 2017, from http://www.enciety.co

World Life Expectancy. (2015). Retrieved July 5, 2017, from http://www.worldlifeexpectancy.com/indonesia-life-expectancy

Worthington, E. L. J., Wade, N. G., Hight, T. L., Ripley, J. S., McCullough, M. E., Berry, J. W., ... \& O'Connor, L. (2003). The religious commitment inventory-10: development, refinement, and validation of a brief scale for research and counseling. Journal of Counseling Psychology, 50(1), 84-96. https://doi.org/10.1037/0022-0167.50.1.84 
1 In my opinion, the president and members of 2018, Vol. 8, No. 2 legislative bodies in central and regional governments can be accountable for the policies they choose including the use of budget to implement the policy.

2 In my opinion, the president and members of the legislative are open and transparent in their chosen policies.

3 In my opinion, the system election of presidential and regional leaders has been going well.

4 In my opinion, the changes of power in the presidency and legislative members are carried out openly and transparently.

5 In my opinion, every citizen has the same chance of occupying a political position.

6 In my opinion, elections have been carried out honestly, fairly, directly, open, and confidential.

7 In my opinion, citizens have the freedom to express their opinions on government policy through newspapers, magazines, radio, television and other mass media.

\section{No II. Religious Commitment}

Disagree

1 I regularly attend religious services.

2 I am a person who is active in my religious activities.

3 God is a top priority in my life

4 In my opinion, religion answers the problems that occur in the life I live.

5 With the teachings of religion, religious teachings encourage me to be honest and obedient to the applicable tax laws.

6 Religion is one of the most important aspects of my life

7 I believe in the management of religious institutions including the integrity of the religious leaders I hold. 
Appendix 1 Questionnaire (Continued)

No

III. Perception of other taxpayers

Disagree

Agree

Questions only for Tax consultants

1 Other tax consultant does not fill tax return according to the actual circumstances, it affects me.

2 Other tax consultant does not do the bookeeping or record income according to the actual circumstances, it affects me.

3 Other tax consultant does not deposit any taxes that have been withheld or that they have picked up, it affects me.

4 Other tax consultant does not register, abuse, or use Taxpayer Identification Number improperly, it affects me.

5 Other tax consultant bribes tax officers, it affects me.

Questions only for Contractors

1 I will make my business partner my reference source in decision making.

2 My business partner is a role model for me in making decisions.

3 My business associate has never experienced tax problems.

4 I do not pay taxes for my additional income, because my business associates do the same.

5 I will not do the tax registering if my business associates who has higher income than me does the same.

No IV. Individual satisfaction Disagree

2 3 4

1

2

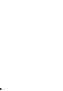


Appendix 1 Questionnaire (Continued)

No V. Trust in government institution

1 The government is able to maintain the sovereignty of the Indonesian state from other countries.

2 The government is able to keep the country from the threat of terrorism, and also prevent any unrest.

3 Personally, I believe in the integrity of law enforcement in Indonesia.

4 I believe that government expenditures are transparent

5 In my opinion, the credibility of high tax employees

6 The Government has supported and provided adequate facilities to the private sector in developing the business.

7 The government has provided administrative services, ease of operation, protection of domestic production well.

8 Indonesia security forces are able to protect and serve the community to create a safe, peaceful, orderly, and peace.

9 The judiciary is able to uphold justice and implement the law according to applicable law.

Questions only for Contractors

10 The Government implements clear rules in taxation on construction services

11 The government facilitated me in the granting of Construction Business License (SIUK), Corporate Registration (TDP), and Construction Service Business Entity Certificate.

Questions only for Tax consultants

10 Document processing procedure for tax consultant permission is easy and fast

11 The central government helps tax consultants who want to ask for a new permit.
Disagree 2018, Vol. 8, No. 2 
Appendix 1 Questionnaire (Continued)

$\begin{aligned} & \text { No } \\ & 1\end{aligned} \begin{aligned} & \text { VI. Tax morale } \\ & \text { Tax laws are the social norms I have to do in my } \\ & \text { life as part of society. }\end{aligned}$
2 I am embarassed if my tax payment does not
$\begin{aligned} & \text { match with the amount I should have paid. } \\ & \text { Reporting main and additional income is }\end{aligned}$
$\begin{aligned} & \text { mandatory. } \\ & \text { Although there is an opportunity to commit tax } \\ & \text { fraud, I will not do it. }\end{aligned}$
$\begin{aligned} & \text { If I have additional income, I will pay tax on that } \\ & \text { income. }\end{aligned}$
$6 \begin{aligned} & \text { I will still pay the actual tax even if the possibility } \\ & \text { of being detected is low. }\end{aligned}$
$\begin{aligned} & \text { I do not feel compelled to pay taxes that I already } \\ & \text { paid. }\end{aligned}$

\section{Copyright Disclaimer}

Copyright for this article is retained by the author(s), with first publication rights granted to the journal.

This is an open-access article distributed under the terms and conditions of the Creative Commons Attribution license (http://creativecommons.org/licenses/by/4.0/). 